\title{
The Language Attitudes of the Community Members Towards Their Local Language, Konjonese of Bulukumba, Indonesia
}

\author{
Abdul Hakim Yassi ${ }^{1}$, Harlinah Sahib ${ }^{1}$, Rezky Ramadhani ${ }^{1}$, Muhammad \\ Aswad $^{2, *}$ \\ ${ }^{1}$ Cultural Science Faculty, Universitas Hasanuddin, Indonesia \\ ${ }^{2}$ Faculty of Teacher Training and Education, Universitas Sulawesi Barat, Indonesia \\ Corresponding author.Email: aswad@unsulbar.ac.id
}

\begin{abstract}
The study reported here aims to figure out the language attitudes of the community members of the Konjonese language, a minority language in the Bulukumba Regency of South Sulawesi Indonesia. It involves three villages of sub-district Bonto Tiro; Batang, Bonto Bulaeng, and Tamalanrea. The study is descriptive quantitative assigning two independent variables; the age group comprising three categories; teenagers, adults, and the olds. The educational background consists of two groups; the less-educated, and well-educated groups. Data were obtained from 45 respondents through questionnaires and additional data were obtained from field observation and interviewing the villages figures such as the village heads, teachers, and religious leaders. The study identified four contributing factors as the skeletal bones of language attitudes; high appreciation to their local language, pride in using their local language, open-mindedness to everyone, and modesty. The study then concluded that the Konjonese language is developed and growing and as such it is relatively safe from endangerment due to the positive attitudes of the community members. A language shift is occurring in the community because of the increased use of the Indonesian language in the community. However, this is not alarming as the community members possess those skeletal bones protecting them from shifting their local language to the other language, including the Indonesian language, from their genuine and natural domains like homes, neighborhood, and the likes. Rather, it results in a stable bilingual for the community
\end{abstract}

Keywords: Language Attitudes, Domains of Language Use, Language Shift, Vitality, and Endangerment

\section{INTRODUCTION}

It has been mentioned in many kinds of literature that another important social factor that plays a very important part in the linguistic vitality of a language is the attitudes of community members toward their own local language. [1]. These studies all agree that the positive attitude of the speakers of the given language contributes positively to linguistic vitality and endangerment of a language and vice versa.

Unfortunately, as UNESCO proclaimed, the community members are not always neutral to their own local language. They promote it when they regard it as important to their community and identity. They may use it but not promote it. They may be ashamed of it and therefore they are not promoting it or they may see it as a nuisance and avoid using it all the time. [2] In a more specific sense, asserted that a language becomes appealing to the speakers who have a positive attitude towards it and prefer it in most interactions. On the contrary, if speakers have negative attitudes towards a language, they develop resistance in using it."

The vast development and increased use of the Indonesian language both as a formal variety and as a colloquial one in all aspects of the daily life of Indonesian people have gradually impacted the domains of heritage languages in Indonesia. [3] who pointed out that, although there has been no data documented yet, the recent observation by some linguists stated that the domains of local languages have been impacted by the increased use of the 
Indonesian language. Similarly, even a decade before, [4] confirmed this phenomenon by stating that Javanese, including Sundanese and Maduranese, with a population of about 84 million has also been categorized as threatened as a result of both the increased use of Indonesian language as the national language and poor intergenerational transmission of the language in the community. Likewise, the Central Statistic Bureau of Indonesia revealed that many local languages have been categorized as threatened as such they need further attention. Also and more related to the present study, [5] have also mentioned that Makassarese with about 2.1 million population and Buginese with about 5 million population of South Sulawesi have been categorized as threatened as well. As such, since the Konjo language is one of the Makassarese dialects, it can be automatically then inferred that the Konjo language is categorized as threatened as well.

Another implication of this phenomenon is more likely to rise anti-thesis to what have been well-known so far claiming that any languages which have a number population less than 100.000 speakers are at risk of endangerment This means that even, languages with big population are not really safe. They conclude that even languages with large populations experience language shifts. It is commonly known that language shift is another determinant factor of language vitality. Without any preventive action, when the language shift keeps on and on, it is then predicted that the given language will extinct. Table 1 below displays the major languages of Indonesia and their level of endangerment based on EGIDS numbers. [5]

Table 1. Spoken languages of Indonesia with over 1 million speakers, based on Lewis et al. 2014 (non-Malayic languages indicated in bold)

\begin{tabular}{|c|c|c|c|}
\hline Language & Region & Population & EGIDS number \\
\hline Java & Java and Bali & $84,300,000$ & 2 Provincial \\
\hline Sunda & Java and Bali & $34,000,000$ & 5 Developing \\
\hline $\begin{array}{l}\text { Indonesian (Bahasa } \\
\text { Indonesia) }\end{array}$ & \multicolumn{2}{|c|}{$22,800,000$} & 1 National \\
\hline Madura & Java and Bali & $6,770,000$ & 5 Developing \\
\hline Minangkabu & Sumatra & $5,530,000$ & 5 Developing \\
\hline $\begin{array}{l}\text { Batak (Toba, Dairi, } \\
\text { Simalungun, } \\
\text { Mandailing) }\end{array}$ & Sumatra & $5,500,000$ & $\begin{array}{l}5 \text { Developing } \\
\text { /6a Vigorous }\end{array}$ \\
\hline Betawi & Java and Bali & $5,000,000$ & 6b Threatened \\
\hline Bugis & Sulawesi & $5,000,000$ & 3 Wider com. \\
\hline Malay & Sumatra & $4,910,000$ & 6a Vigorous \\
\hline Aceh & Sumatra & $3,500,000$ & 5 Developing \\
\hline Banjar & Kalimantan & $3,500,000$ & 3 Wider com. \\
\hline Bugis & Sulawesi & $3,500,000$ & 6b Threatened \\
\hline Bali & Java and Bali & $3,330,000$ & 5 Developing \\
\hline Musi & Sumatra & $3,105,000$ & 3 Wider com. \\
\hline Makasar & Sulawesi & $2,130,000$ & 6b Threatened \\
\hline Sasak & Nusa Tenggara & $2,100,000$ & 5 Developing \\
\hline Gorontalo & Sulawesi & $1,000,000$ & 6b Threatened \\
\hline Malay, Jambi & Sumatra & $1,000,000$ & 6a Vigorous \\
\hline
\end{tabular}

As can be seen from the table, the EGIDS number of major languages in Indonesia with population over
1 million range from a 2 (Provincial) to $6 \mathrm{~b}$ (Threatened). The smaller the number the safer the 
language. The EGIDS number of Makassarese language of South Sulawesi is $6 \mathrm{~b}$ (Threatened). This could mean then Konjo language is also at risk of endangerment as it is a dialect of Makasarese language.

\subsection{The Objectives}

The study reported here is aimed at figuring out the language attitudes of the community members toward their own local language, Konjonese of Bulukumba regency of South Sulawesi, Indonesia. Moreover, as a comparable finding, it is also designed to figure out their language attitudes toward their national language, Indonesian, and the international language especially English.

\subsection{Konjo Language of Indonesia}

The linguistic landscape of Indonesia is regarded overwhelmingly complex and dynamic. [3] pointed out that Indonesia is the second most multilingual nation in the world with population 258 million. As identified by the Ethnologue, there are 706 living languages in Indonesia, implying that around 10 percent of the living languages listed worldwide[5]. One of them is the Konjo language (Konjonese)

Congolese comprises two varieties; Highland Konjo which is mostly spoken in the Tinggi Moncong sub-district and scattered over in the adjacent villages of Gowa and Sinjai regencies with population around 150.000 speakers, and Coastal Konjo which is mostly spoken in coastal areas of Bulukumba regency, Bone gulf, and Southeast Sulawesi with population around 170.000 speakers (Wikipedia). The study reported here is focused on the coastal Konjonese.

Up to now, there is still an inconclusive debate about the status of Konjonese. Some linguists claimed Konjo as a dialect of Makassaric, see for example Some others regard it as a language by itself, separated from Makassaric, However, the discussion is not geared toward responding to this contradictory view.

The Distribution of Konjonese in Bulukumba Regency

The following map illustrated the research sites and the distribution of Konjonese sepakers in Bulukumba regency.

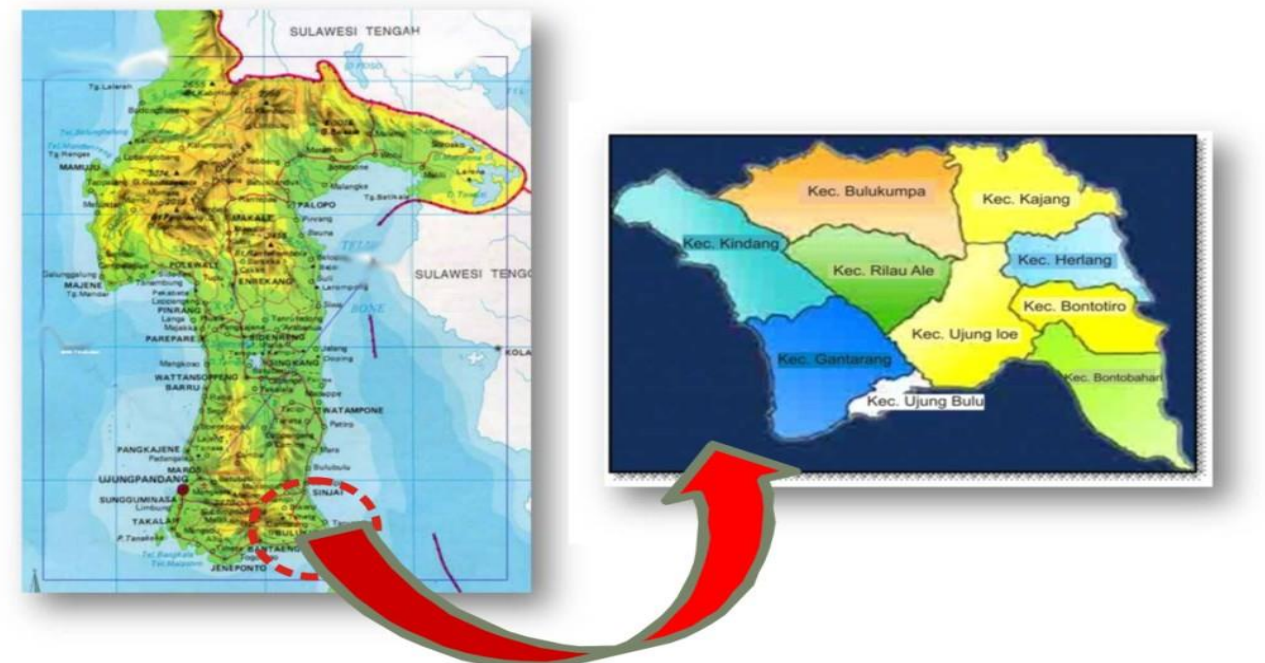

Figure 1 Map of South Sulawesi and Bulukumba Regency

As can be seen from the map above, Bulukumba regency is situated at the southern part of South Sulawesi province. It exactly lies in the two coastal sides, southern and eastern sides. Bulukumba is commonly known as the Buginese area by lay people. However, in general, it consists of two ethnic groups. Buginese inhabits the western part of Bulukumba regency comprising 4 sub districts; Gattareng, Bulukumpa, Rilau Ale, and Ujung Loe. Coastal
Konjonese inhabits the eastern part of Bulukumba regency consisting of 4 sub-districts; Bonto Bahari, Bonto Tiro, Herlang, and Kajang. Another subdistrict, Kindang, is inhabited by Highland Konjo.

The Ethnologue identified Coastal Konjo as ISO639-3 kjc, the alternate name is Konjo, Tiro, user population 167.000 which inhabit Bantaeng, Bulukumba, and Sinjai regencies; southeast 
peninsula on Selayar strait of South Sulawesi. Language status is $6 \mathrm{~b}$ (threatened).

The study reported here was carried out in three villages of the Bonto Tiro sub-district of Bulukumba regency, they are villages of Batang, Bonto Bulaeng, and Tamalanrea with a population 21.390 in 2019 ( $5 \%$ of the total population of Bulukumba). As can be seen from the map above, the three villages understudy is concentrated in the nucleus part of Konjonese speakers in Bulukumba regency.

\section{METHOD}

The study design is survey in nature assigning two independent social variables; Age groups, and Educational Background. The age variable comprises three groups; the teenagers are those who are aged $\leq$ 35 years, the adults are those who are aged 36-59 years old, and the olds, $\geq 60$ years old. The educational background is grouped into two; Lesseducated covering those who are the high school certificate holders and less, and Well-educated, those who are the holders of the undergraduate certificate and above. The study involves three villages of Bonto Tiro Sub-District of Bulukumba District of South Sulawesi, Indonesia in which Konjo language speakers reside and live. These three villages are Batang, Bonto Bulaeng and Tamalanrea. Of 420.603 people as the total population of Bulukumba District in 2019, only about 5\% (21.390 people) live in Bonto Tiro Sub-district The Central Statistic Bureau of Bulukumba Regency, 2021.

Data were obtained from 45 Konjo language speakers as the samples of the study in the three villages through a questionnaire developed. [3] As such, each village consists of 15 respondents. Other related and supporting information were obtained from field observation and interviewing the community leaders and figures such as the head of the villages, school teachers and principals, the religious leaders, and so forth.

The data analysis presented here is the compilation of the interview questionnaire results and the author and research assistant's observation while visiting the three villages as the research sites. At first, the data from the questionnaires are sorted out and classify them in terms of their own categories and characteristics and then they are put in a tabular form. After that, the data are tabulated based on the independent social factors such as the intergenerational transmission of the language, the community language attitude, and the patterns of the language use of the community and the likes. Finally, all the related data are displayed in a diagrammatic form to allow the researcher to have a more comprehensible interpretation of the given phenomena.

\section{RESULTS}

The following figures illustrated the language attitudes of the community members towards their local language, Konjonese, and the national language, Indonesian, and the international language, English.

\subsection{The Respondents' Language Attitudes toward Their Local Language, Konjonese}

Figure 1 up to Figure 7 illustrated the respondents' language attitudes toward their local language, Konjonese.

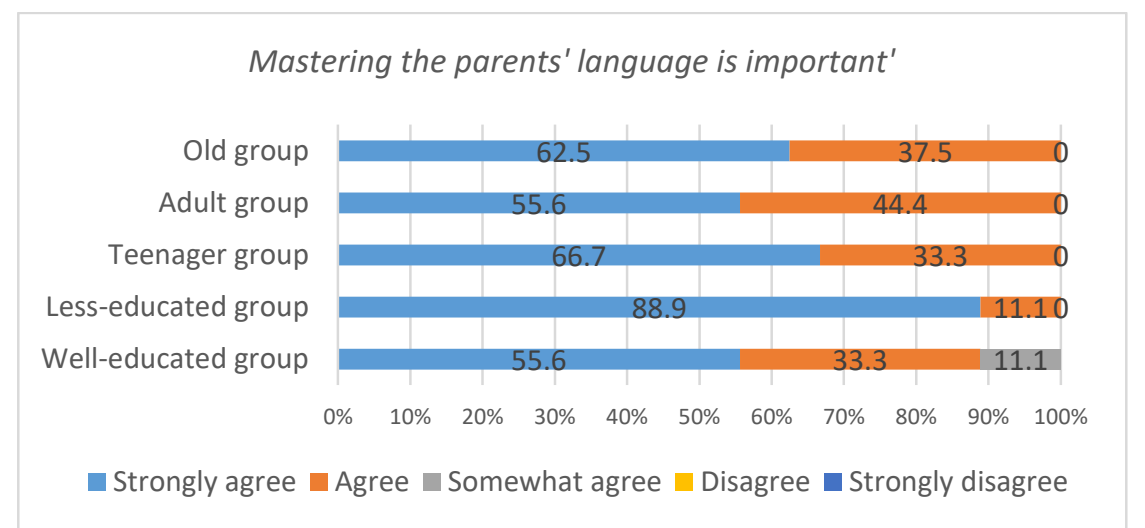

Figure 2 Respondent's response to the statement, 'mastering the parents' language is important 
As can be seen from the figure, all respondents agree that the parent's language is important, no respondents even denied this. The differences just lied on the portion of their agreement. The teenagers and the less educated ones underscored the other groups by choosing 'strongly agree', taking up about $66.7 \%$ and $88.9 \%$ of the data respectively. Without any hesitation, these two groups regarded the parents' language as really important.

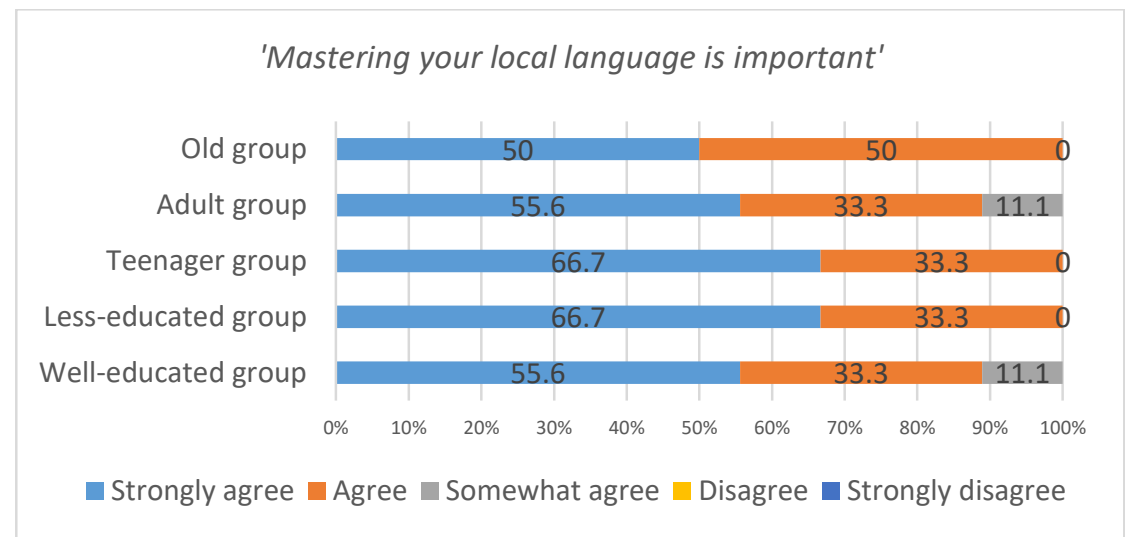

Figure 3. Respondent's response to the statement, 'mastering your local language is important'

As can be seen from the figure above, although the respondents all agree that mastering their local language is important, again, the teenagers and less educated groups are found to be the most dominant compared to the other groups. They chose 'strongly agree' in responding to the statement above taken up about $66.7 \%$ of the data respectively. No respondents refused this statement.
This phenomenon indicates a positive trend to the linguistic vitality of Konjonese because the young generation who plays a very crucial part in the linguistic vitality and endangerment of a language show a positive attitude toward their local language.

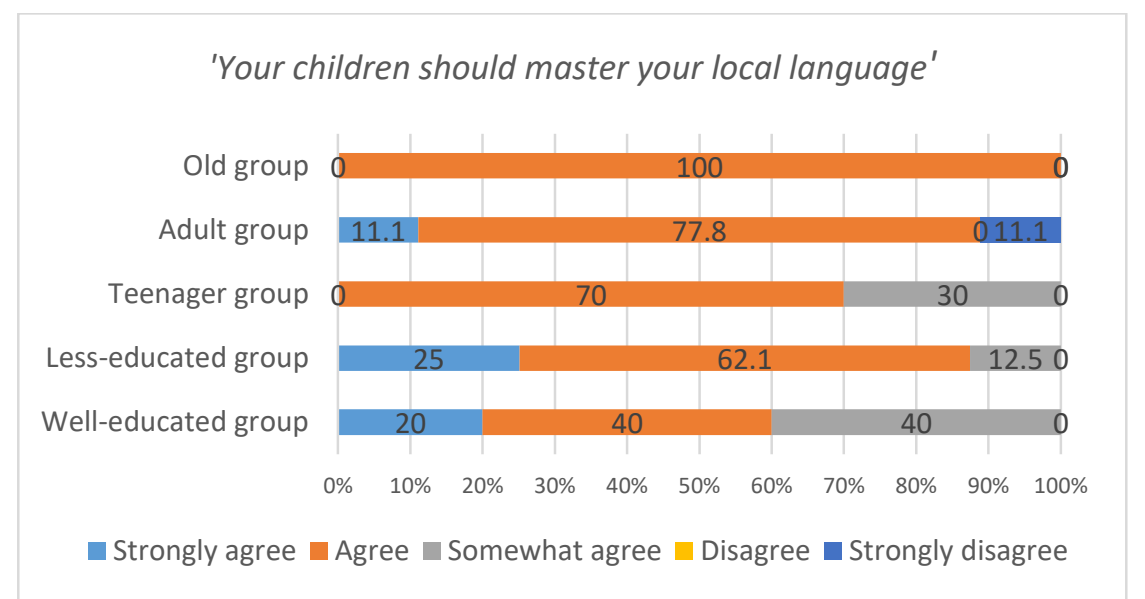

Figure 4 The Respondents' response to the statement, 'your children should master your local language

The figure above indicates most of the respondents agree that the children should master their local language, Konjonese, occupied $81.2 \%$ of the data. Only $11.1 \%$ who refused the statement. The old group is found to be the most dominant among the other groups, by choosing 'strongly agree' in responding to the statement above, taking up $100 \%$ of the data.
Again, this phenomenon denoted a positive attitudes of the community members toward their local language, Konjonese. As a result, this will contribute significantly to the high vitality of their local language, in particular when the younger generation puts a positive attitude and concern for their local language.
Again, the less educated group underscored the welleducated one.

This phenomenon also denoted a supporting factor to the linguistic vitality of Konjonese, as all community members agree that the children should master their local language. These positive attitudes will have a positive impact to among others the 
process of intergenerational transmission as this becomes another important factor in defining language vitality. In consequence, all the parents feel obliged to educate their children in Konjonese and effectively and actively use Konjonese in their daily interaction.

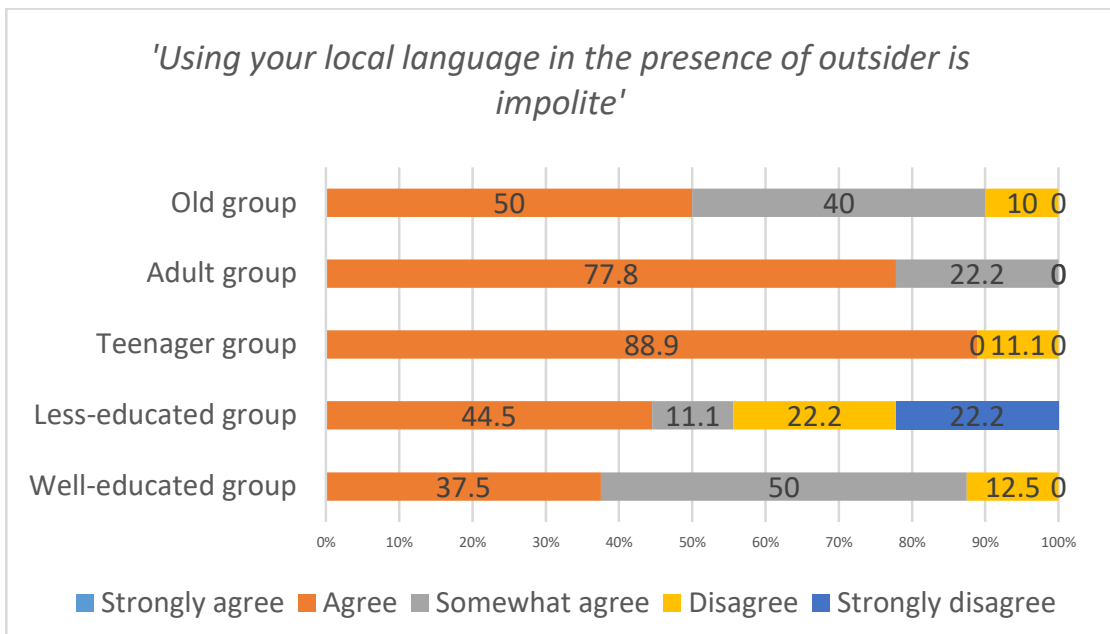

Figure 5 The Respondents' response to the statement, 'using your local language in the presence of outsider is impolite

The figure above illustrated the respondents' response to the statement saying 'using your local language in the presence of outsider is impolite'. It is found that most respondent agree to the statement, occupied almost $60 \%$ of the data, and some others do not, taken up only $22.7 \%$ of the data. It is found the teenagers underscored the other groups in affirming the statement, occupied $88.9 \%$ of the data. On the contrary, the less-educated group is found to be dominant in negating the statement, occupied $44.4 \%$ of the data.
This indicates two contradictory attitudes of the community members in responding to the statement. On the one hand, the phenomenon indicated that even though, the community members are proud of and highly appreciate their local language, they think that behaving politely to anyone is another important factor to have in their social interaction. On the other hand, those who do not agree about the statement, do not mean that they are impolite. They are just likely to have a remarkable sense of proudness of their local language. As such, they are more likely to use their local language wherever they are.

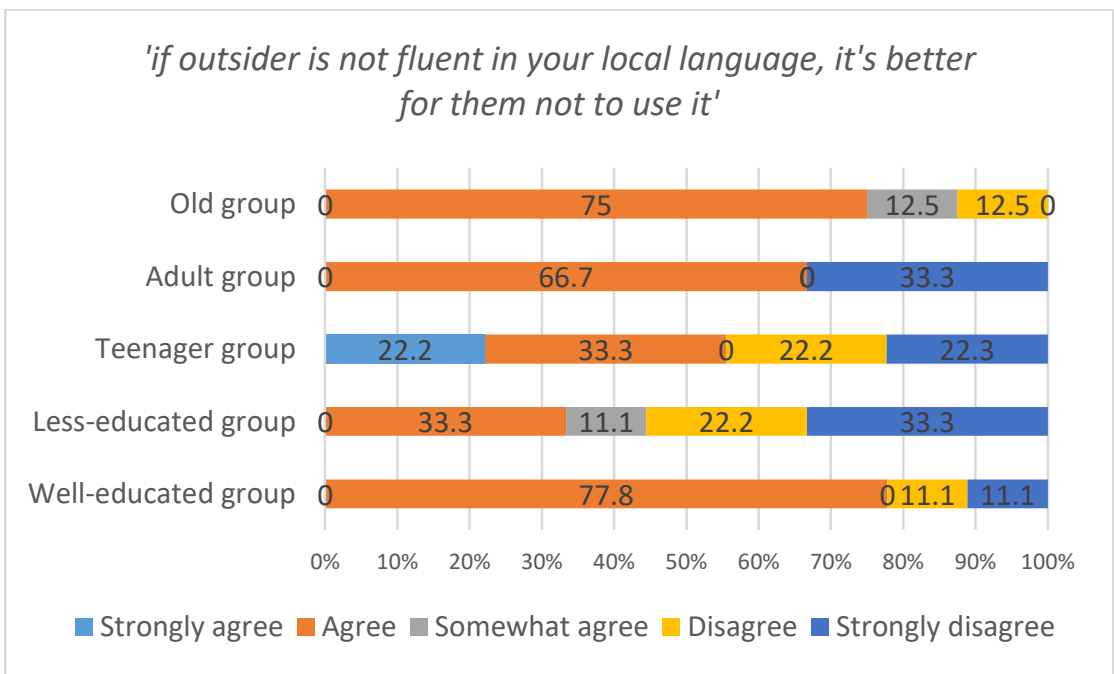

Figure 6 The Respondents' Response to the Statement, 'if outsider is not fluent in your local language, it's better for them not to use it 
As can be seen from the figure above, the respondents' response to the statement stating that if outsider is not fluent in your local language, it's better for them not to use it in communication. It is found there are two contradictory responses to this statement. Some of them agree to the statement, taken up $61.7 \%$ of the data. Some others are disagreed to the statement, occupied 33.6 of the data. The welleducated group is found to be dominant in affirming the statement, occupied $77.8 \%$ of the data. The former implies that the community members simply try to preserve the originality of their local language as they believe that variation of a language is motivated by among others a language contact of the two different languages. As a consequence, this contact will result in mixing of the two languages in one episode interaction or switching from one language to the other or for sure the dominant language will affect the minority language. The latter implies that the community members are welcome all people to use their local language regardless of the unintelligible forms they produced. This open-mindedness is a contributing factor to the language vitality as the number of users' increase.

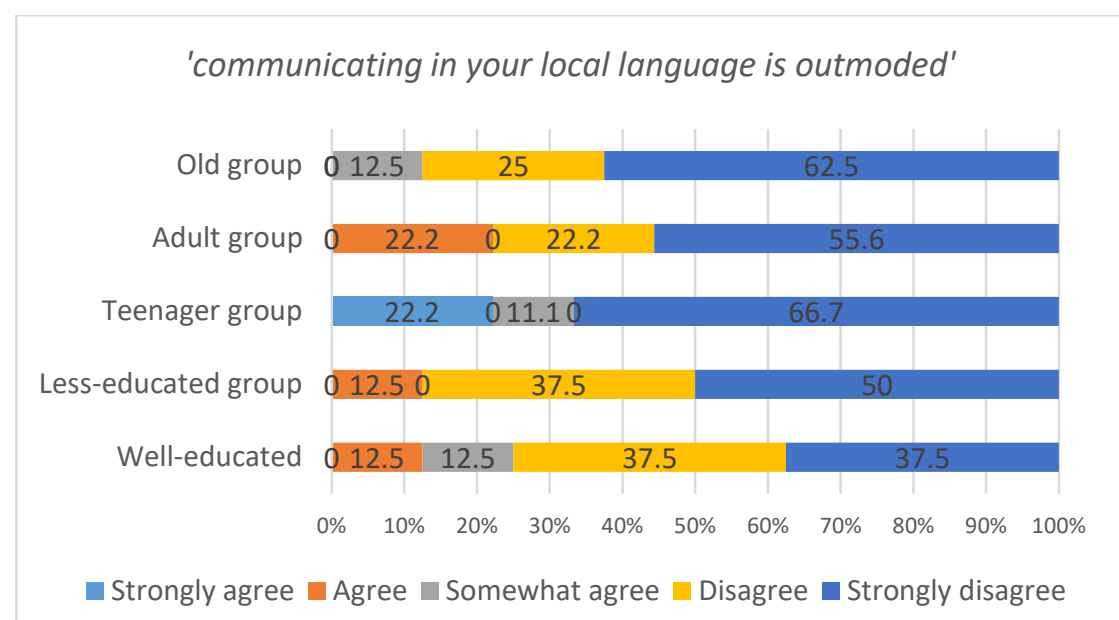

Figure 7 The Respondents' Response to the Statement, 'communicating your local language is outmoded.

The figure above illustrated that mostly respondents are disagreed to the statement stating that communicating in your local language is outmoded, taken up about $80 \%$ of the data. Of this amount, more than half of the respondents $(56 \%)$ are strongly disagreed on this statement. Again, this phenomenon indicated the respondents' proudness of their local language. They do not care about such a negative attribute. All they care is using their local language whenever and wherever they are. What is the most interesting one, when we take a closer look to the diagram above, it is found the teenagers again to be the most dominant among the other groups in refusing this statement by choosing 'strongly disagreed', taken up about $66.7 \%$ of the data. This implies that whenever and wherever the community member engages in an interaction, they are more likely to choose their local language as a medium of interaction rather than other languages. This is confirmed by the researchers' field observation where he almost has never heard other language using by the community in their daily interaction, including the children. 


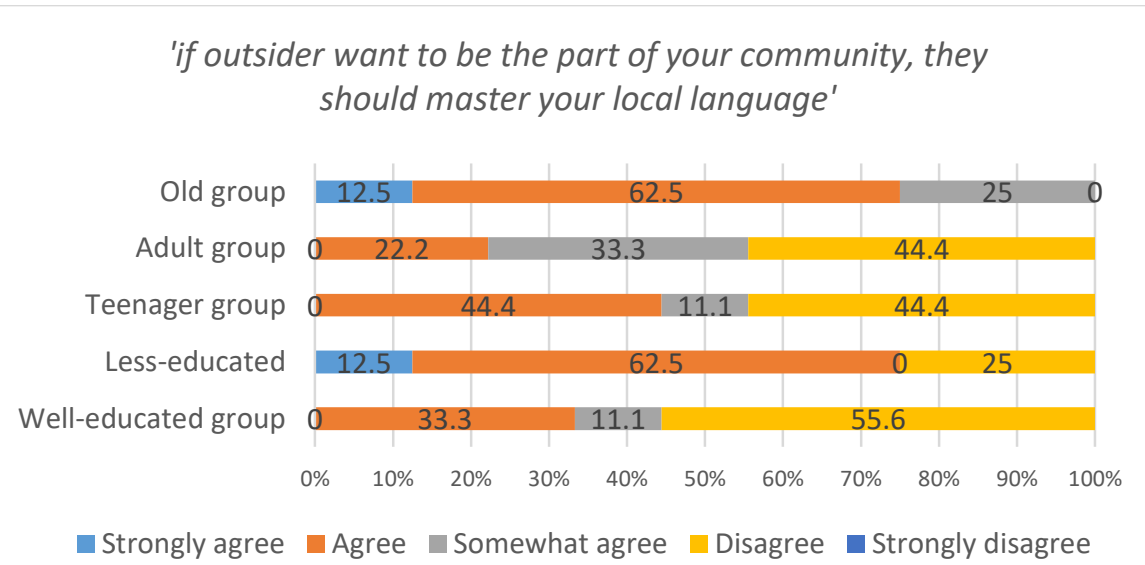

Figure 8 The Respondents' Response to the Statement, 'if outsider want to be the part of your community, they should master your local language'

The figure above shows a contradictory view in responding the statement stating if the outsider wants to be part of your community, they should master your local language. Some respondents are agreed on the statement, taken up about $60 \%$ of the data. Some others are disagreed, taken up about $40 \%$ of the data. The old and the less educated groups underscored the others groups in affirming the statement, taken up $62.5 \%$ of the data respectively. In contrast, the welleducated group is found to be the most dominant in refusing the statement, taken up $55.6 \%$ of the data. The phenomenon implies that these two different sides are all regarded positive to their local language vitality. Those who confirms the statement enable to increase the users of their local language. Besides, they are in the line of thesis advocating that total and comprehensive immersions of one particular culture is preceded by the mastery of the language of the culture. On the contrary, those who refused the statement are opened to all people who want to be part of their community by arguing that once when the outsiders have intermingled in the community, it is then automatically and gradually learn the community language. This open-mindedness plays a vital role in the linguistic vitality of a language. Therefore, the standpoint of the teenager is in between the two polar. Some agree and some disagree because they think both views are all constructive to the language vitality of Konjonese.

\subsection{The Respondents' Language Attitudes toward their National Language, Indonesian}

The following 3 figures illustrated the respondents' language attitudes toward their national language, Indonesian language.

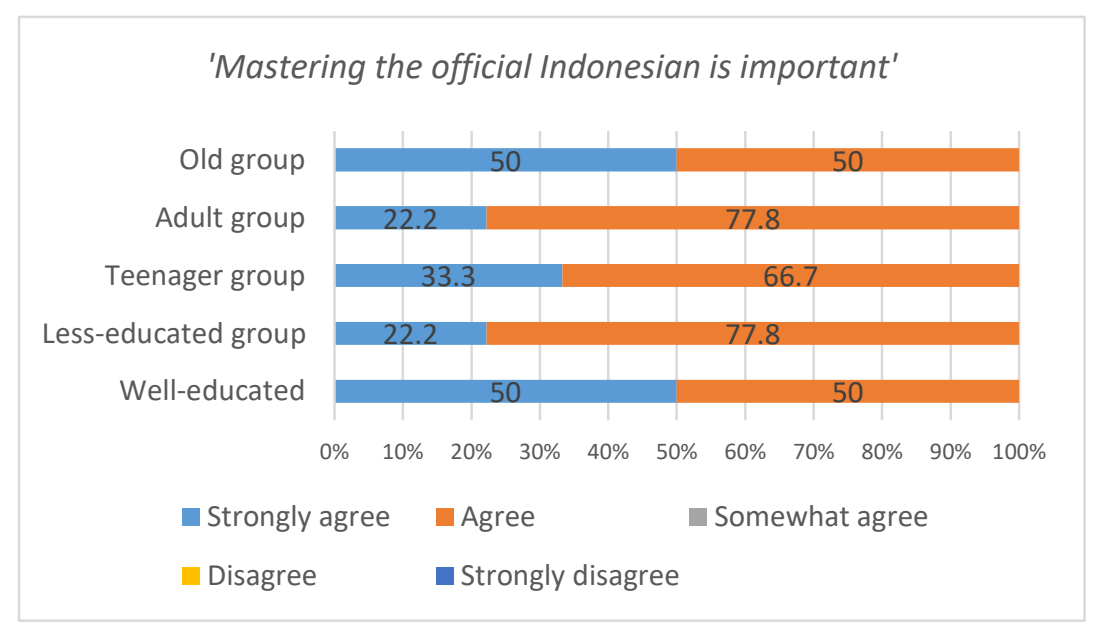

Figure 9 The Respondents' Response to the Statement, 'mastering the official Indonesian is important 
As can be seen from the figure above, all groups confirmed that mastering the official Indonesian is important. $35 \%$ of the data chose 'strongly agree' to the statement and $65 \%$ of the data chose 'agree' to the statement. This implies that the community members consider Indonesian language is important as it is the national language used as a lingua franca for communication of different language background participants. Moreover, they think that as the national language, Indonesian language is used for a wider communication especially in more formal domains.

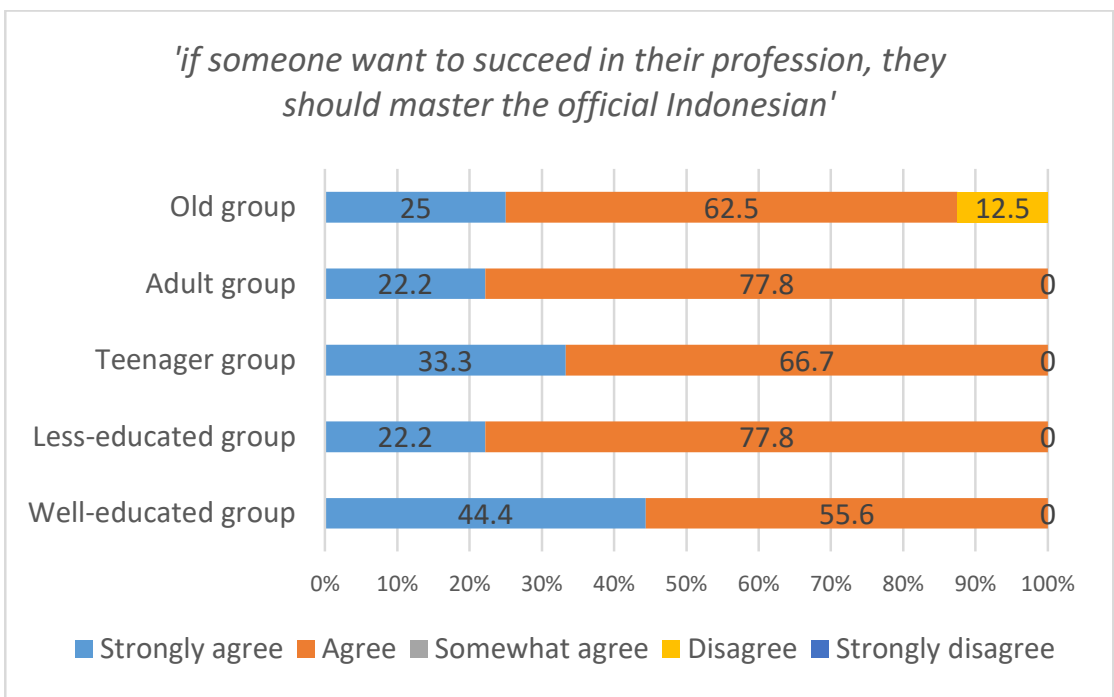

Figure 10 The Respondents' Response to the Statement, 'if someone want to succeed in their profession, they should master the official Indonesian

As can be seen from the figure, almost all the respondents affirm the statement stating that if someone wants to succeed in their profession, they should master Indonesian language. $29.4 \%$ chose 'strongly agree' and $68.1 \%$ chose 'agree' and only $2.5 \%$ chose disagree. It is found the well-educated group to be the most dominant in the groups of choosing strongly agree, taken up $44.4 \%$ of the data. The adult and less-educated groups are found to be the most dominant in the groups of choosing 'agree', occupied $77.8 \%$ of the data respectively.

This implies again that the respondents relatively realized that the important role of Indonesian language in a wider communication, especially in a more formal domain such as at work place, businesses and education including in mass media. 


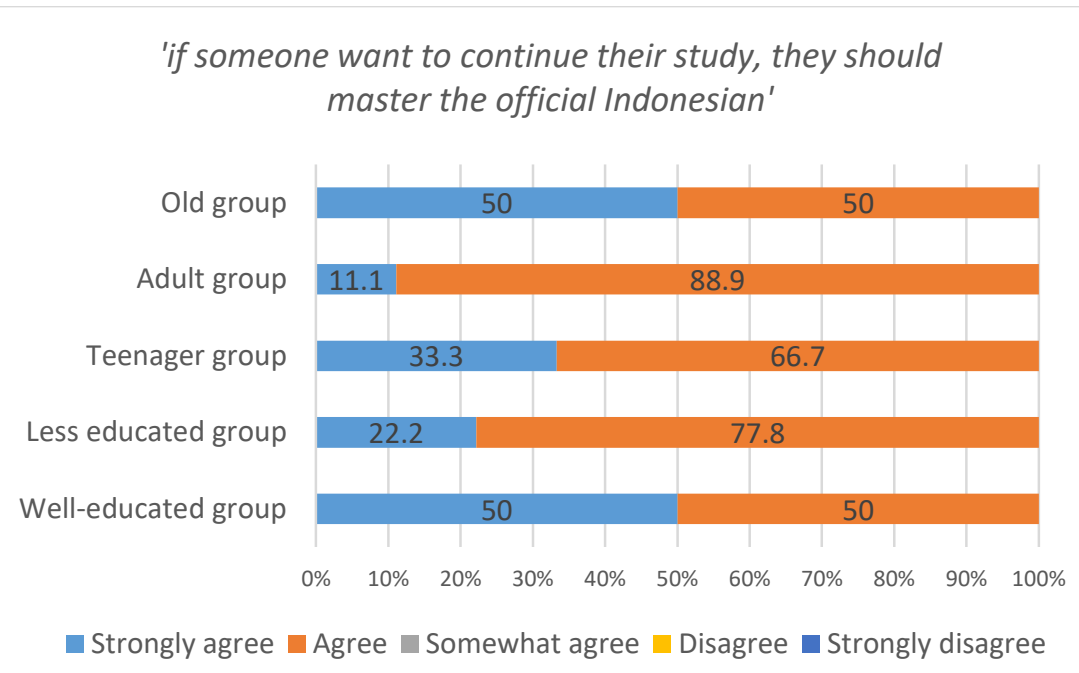

Figure 11 The Respondents' Response to the statement, 'if someone to continue their study, they should master the official Indonesian'

Figure 10 above illustrated the respondents' response to the statement stating if someone wants to continue their study, they should master the official Indonesian. It is found that all the respondents affirm this statement well as no one denies it. $33.3 \%$ chose strongly agree which is dominated by the old and educated groups, occupied $50 \%$ of the data respectively and $66.7 \%$ chose agree which is dominated by the adult group, taken up $88.9 \%$ of the data.

This phenomenon indicates again the privilege status of Indonesian as the national language. The community members realize this status well, and as such, they feel obliged to master official Indonesian for their future better careers. Even, for those who are less-educated ones as shown by the diagram above, they dominated all other groups.

\subsection{The Respondents' Language Attitudes toward the International language, English}

The following three figures illustrated the respondents' language attitude toward the international language, English.

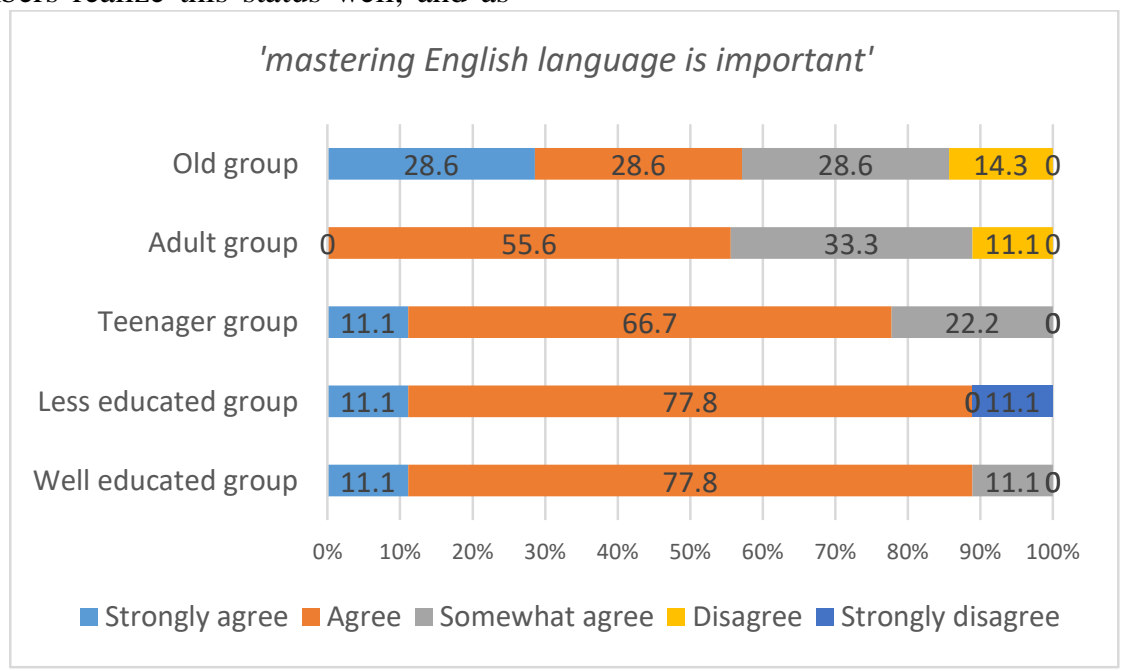

Figure 12 The Respondents' Response to the Statement, 'mastering English language is important'

As can be seen from the figure above, most of the respondents affirm the statement stating mastering English language is important, taken $73.3 \%$ of the data. It is found the old group to be dominant in the groups of choosing strongly agree, taken $28.6 \%$ of the data. The only group which denoted a refusal of the statement is the less-educated one, taken $12.2 \%$ of the data. Although, they are not the dominant, teenagers shows completely agree to the statement. 


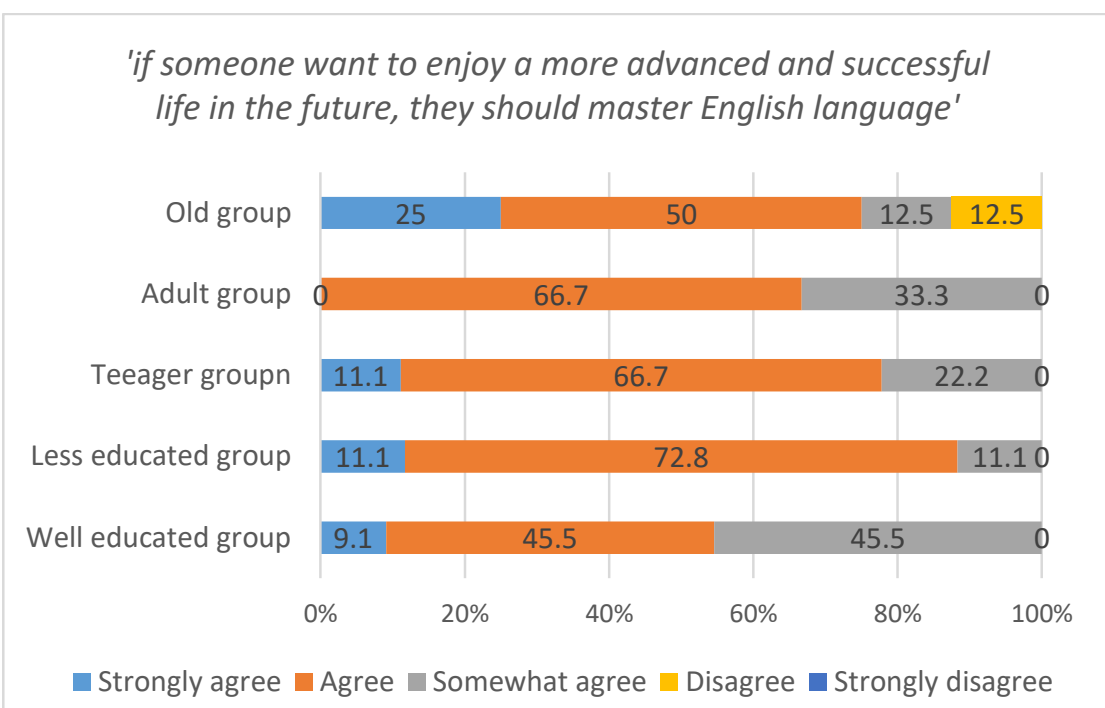

Figure 13 The Respondents' Response to the Statement, 'if someone want to enjoy a more advanced and successful life in the future, they should master English language

The figure above illustrated the respondents' response to statement stating that if someone wants to enjoy a more advanced and successful life, they should master English. Most respondents agree on this statement, taken up 71.6 of the data and only $2.5 \%$ refused this statement. It is found the lesseducated group to be the most dominant in affirming the statement, occupied $72.8 \%$ of the data. The teenager group completely agree on this statement.

This phenomenon implies that the community members also realized the important role of English language as the international lingua franca for global interaction. Even, this positive trend is denoted by the less-educated group.

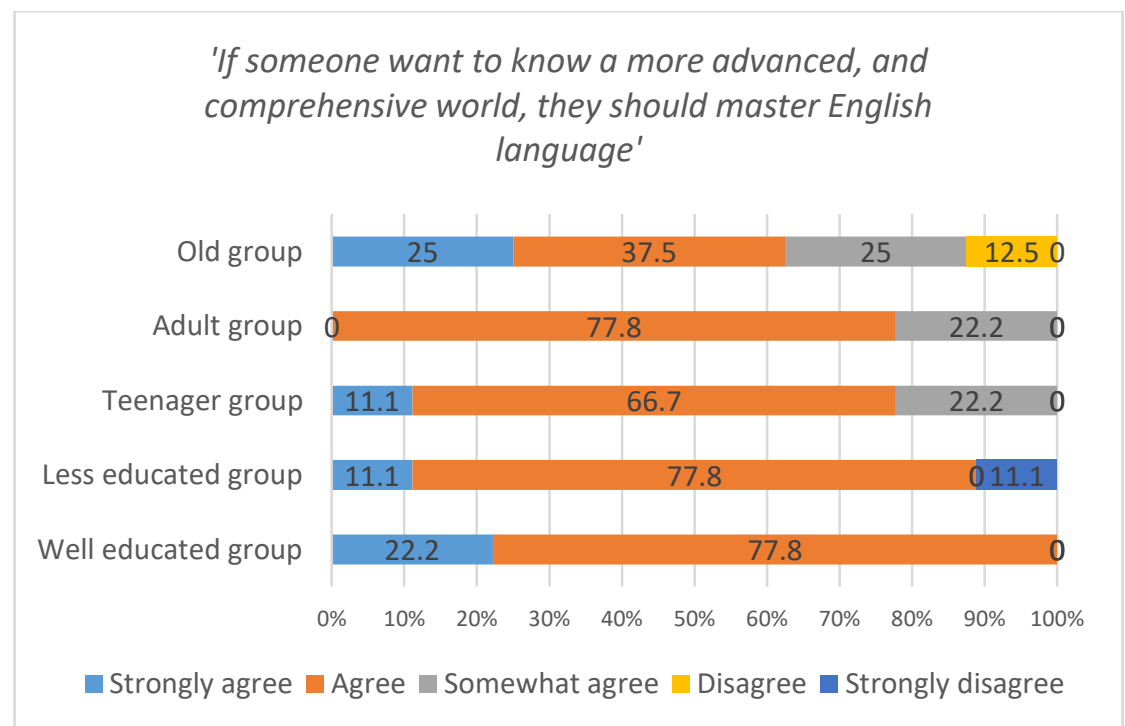

Figure 14 The Respondents' Response to the Statement, 'if someone want to know a more advanced and comprehensive world, they should master English language'

As can be seen from the figure, most of the respondents affirm the statement stating if someone wants to know a more advanced and comprehensive world, they should master the English language. $81.4 \%$ of the respondents affirm this statement. This is 
mostly dominated by the adult, the teenager, and welleducated groups.

The phenomenon implies that the community members realized the vital role of English as the international language for global communication. Among the three dominant groups, the language attitudes of the old and the teenager groups are considered to be the most significant attitudes among others. This is because the old generation will equip their children to master the English language as well assuming that the children will enjoy a future better life. In the same vein, the teenagers realized this earlier and as such they will constitute themselves with this international language for they better future life.

\section{DISCUSSION}

\subsection{The Respondents' Language Attitudes toward their Local Language, Konjonese}

As mentioned above, the primary social factors used in the present study are age groups and educational background. This enables the researcher to have a much clearer picture of the community member language attitude toward their local language, Konjonese and to Indonesian and English as the national and international languages respectively by focusing attention on the language attitudes of the young generation. This is in line with [3] who asserted that the examination of age allows us to measure the success of intergenerational transmission. As it is commonly known that the young generation, especially children, is an effective indicator for language vitality assessment. When a language is actively used by the youth, including children, at home, and they have a positive attitude toward their local language, this indicates that the language is safe from endangerment. Moreover, the focus also is put in educational backgrounds to figure out the interplay between educational background and language attitudes.

The youth is found to be the most dominant among the other groups in giving a high appreciation for their local language. This is indicated by the high rating in affirming the statements stating that mastering the parents' language is important, (66.7\% of strongly agree, Figure 1), that mastering the local language is important (66.7\% of strongly agree, Figure 2$)$, and that the children should master your local language $(70 \%$ of agree, Figure 3). Moreover, another contributing factor to the linguistic vitality of the Konjonese language by the youth is the proudness of their own local language. This is denoted by their high rating in refusing the statement that communicating in your local language is outmoded, taken $66.7 \%$ of the data, they chose strongly disagree in response to the statement (Figure 6).
Another picture that is worth mentioning is the highest rating of the youth's affirmation to the statement that using your local language in the presence of outsiders is impolite. This implies that the youth realized that they live side by side with other ethnic groups, such as Buginese, Makassarese, Javanese, etc. They should pay a respect to the outsiders. Respecting one another is a universal cultural value as this will result in a social harmony in the community. [6]who pointed out that caring others started from neighborhood, people in the same village, people in the same area, the same generation, close friends, and the likes are all regarded as contributing to social harmony.

The rests, although the youth is not dominant, they still respond positively to both statements that if outsiders are not fluent in your local language, it's better for them not to use it (Figure 5), and that if outsiders want to be the part of your community, they should master your local language (Figure 7). Being modest and open-minded, the youth responds positively to the last two statements, $50 \%$ agree and $50 \%$ disagree. This figure shows that they do not mind the outsiders using their local language unintelligibly, ill-formed, as they believe this is just a learning process, it is developing. In the same vein, they do not push outsiders to have a good mastery of their local language before becoming a part of their community. Rather, they let it to happen naturally as learning a language naturally will speed up the learners' communicative competence. [7]

The other most crucial social factors related to the language attitudes of the community members in defining the linguistic vitality of a language is the intergenerational transmission process of the language. If the process is disrupted it is predicted that the language is at risk of endangerment, and vice versa. [8] asserted that the causal factors of shift and disruption of intergenerational transmission are largely social. Similarly, [5] admitted that Fishman's GID focuses on the key role of intergenerational transmission in the maintenance of a language. Further, they pointed out that parents should transmit their language to their children who are in turn be able to pass the language as well on to their children one day. Similarly, [9] asserted that when parents choose not to use their mother tongues to communicate with their children, the children will not be able to acquire their parents' mother tongues. If this situation happens continuously, it may lead to the extinction of the language, and it proves that language attitude and language choice influence the vitality of language.

As it becomes clear now, that the vital role of the old generation, in this sense, the parents are inevitable. The followings are the illustration of the language attitudes of the older generation, including the parents. As displayed at Figure 1 to Figure 3, the older 
generation, in this regard, the adult and the old groups, denoted a positive respond to the statement that mastering the parents' language is important, and that mastering your local language is important, and that your children should master your local language. Even, in this last statement, the old group is completely agreed $(100 \%)$. As a matter of fact, almost no respondents refused this three statement. The differences are only resided in the portion of choosing between strongly agree and agree. Moreover, parents are scattered over in all groups for exception the teenager group. This implies that all of the parents that included in the groups under study believe that their local language is really important and valuable, and as such they feel obliged to pass their local language to their children and the children will do the same thing as their parents do once they have their own family. As a result, this will contribute significantly to the success of the intergenerational transmission of their local language. Eventually, it increases the linguistic vitality of Konjonese.

As for the interplay between the educational background and the language attitudes, it could be said that there is more likely no vivid connection of the respondents' educational backgrounds and their language attitudes. This can be inferred from the data from Figure 1 to Figure 7 illustrating the respondents' language attitudes to their local language, Konjonese. As can be seen from these figures, the less-educated group completely underscored the well-educated one in all statements. They chose 'strongly agree' in responding to all statements more than the welleducated one. The well-educated group seems to underscore the less-educated one in their language attitudes toward the national and international languages, Indonesian and English respectively as far as the 'strongly agree' response is concerned. However, when the 'strongly agree' response is combined with the 'agree' response, it is found then the two social variables share a similar portion of the agreement for all statements. This is a peculiar thing and as such it is somewhat complicated to elucidate.

It could be said then that the less-educated group is more inclined to using their local language in all of their daily interaction than the well-educated one. This is more likely to be driven by their high sense of belonging and their proudness of their local language. On the contrary, the well-educated group is more likely to be open-minded in responding to the phenomenon of the increase use of Indonesian language in formal domains and English language in a global perspective.

\subsection{The Respondents' Language Attitudes toward their National Language, the Official Indonesian}

It is found that most of the respondents are realized the vital role of the official Indonesian in a much wider communication especially in a more formal domain such as at work places, businesses, educations, government, mass-media and so forth. Therefore, without any hesitation, most of them affirm the statement that mastering the official Indonesian is important (Figure 8), also, that if someone wants to succeed in their professions, they should master the official Indonesian (Figure 9), and likewise, that if someone wants to continue their study, they should master the official Indonesian (Figure 10).

However, the increase use of Indonesian both as the official variety and as the colloquial one has gradually impacted the natural domains of local languages in Indonesia. This phenomenon has been confirmed by some studies that were carried out in Indonesian context including. [3-5] This phenomenon automatically implies that a language shift is occurring and growing in the community. As a matter of fact, the use of Indonesian in any aspect of life in Indonesia is inevitable. When this phenomenon is getting bigger and bigger and there is no follow-up and preventive actions taken by the concerned parties such as government, linguists, community leaders, it is then predicated that the language will extinct one day.

\subsection{The Respondents' Attitudes toward the International Language, English}

It is found that the respondents' language attitudes to the English language is relatively positive. Such a positive attitude is denoted by the respondents' response to the statements that mastering English is important, and if someone wants to enjoy a more advanced and successful life in the future, they should master English, and that if someone wants to explore a more advanced and comprehensive world, they should master English language. Most respondents affirm these statements. Even, it is found the teenager and the well-educated groups underscore the other groups in the three statements. Unfortunately, such a positive attitude toward English language are not in parallel to their English proficiency. Indonesian people in general and Indonesian students in particular is found to have a relatively low mastery of English and as such they could not use English well in real communication $[6,7,10]$ found that most students perform poorly in speaking and writing due to lack of motivation and unsatisfactory learning style. 


\section{CONCLUSION}

As it becomes clear now, the linguistic vitality of a language involves many interrelated social factors. However, it could be said that language attitudes of the community members is the most crucial one as it could impact the other social factors such as the intergenerational transmission, domains of language use, speaker number trend, and so forth.

The study has identified that at least there are four contributing characteristics the community members should possess enabling them to increase the linguistic vitality of their local language. They are (1) highly appreciate their local language, (2) proud of using their local language everywhere, (3) being modest to outsiders and neighbors, and (4) being open-minded to everyone. These four positive factors are regarded as the skeletal bone of the language attitudes enabling the language vitality stand erect and developed.

The study then concluded that Konjonese language is developed and growing and as such it is relatively safe from endangerment due to the positive attitudes of the community members. A language shift is occurring in the community because of the increase use of Indonesian language in the community is inevitable. However, this is not alarming as the community members possess those skeletal bones protecting them from shifting their local language to the other language and being eradicated from their genuine and natural domains like homes, neighborhood, and the likes. Rather, it results in a stable bilingual for the community. Finally, it could be said that there is more likely no vivid correlation between the respondents' educational background and their language attitudes

\section{ACKNOWLEDGMENT}

We would like to thank the Konjonese community members in villages of Batang, Bonto Bulaeng, Tamalanrea, and Bonto Tangnga of Bonto Tiro subdistrict of Bulukumba regency for their active participation in the investigation, especially for the chief of these villages. Our great gratefulness should also go to the Rector of Hasanuddin University of Makassar and the members of Institute for Research and Community Service of the university for financing the study. Finally, we would like to express our gratitude to the management of Cultural Science Faculty of Hasanuddin University of Makassar for facilitating and supporting the study.

\section{REFERENCES}

[1] Holmes J. An introduction to sociolinguistics. 4th ed. INGGRIS: Routledge; 2013.

[2] Dweik BS, Qawar H. Language choice and language attitude in a multilingual Arab Canadian community. British Journal of English Linguistics 2015;3:1-12.

[3] Abtahian MR, Cohn, Pepinsky T. Modelling Social Factors in Language Shift. IJSL 2016;4:137-70.

[4] Adeelar AK. Language Documentation in the West Austronesian World and Vanuatu: An Overview. Endangered Languages of Austronesia 2010:12-41.

[5] Lewis MP, Fenning CD, Simons GF. Ethnologue: Languages of the World. 7th ed. SIL International; 2014.

[6] Abdul HY. Effective Numbers of Small Group Work Members in Improving Learners' Grammar and Speaking Competence in English Grammar Classrooms: Interactive Vs Conventional Teaching Method. The Asian ESP Journal 2020;16.

[7] Abdul HY. Ancangan model interaksi kelas terhadap pembelajaran gramatika Bahasa Inggris dalam rangka meningkatkan kompetensi Bahasa Inggris mahasiswa: Kajian Eksperimental. Makasar: 2010.

[8] Fishman JA. Reversing Language Shif. Multilingual Matters 1991.

[9] Fitriani A, Magdalena M, Wardani S. Language Attitudes and Language Choice among Students in Yogyakarta: A Case Study at Universitas Sanata Darma. International Journal of Humanity Studies 3(2). International Journal of Humanity Studies 2020;3:239-50.

[10] Abdul HY. Model pembelajaran Gramatika Bahasa Inggris berbasis interaktif, "Paired Interaction", dalam rangka meningkatkan Kompetensi Bahasa Inggris Mahasiswa. Kajian Quasi Eksperimental Lensa Budaya 2010;5:80-90. 